\title{
Denervation of the paraspinal muscles in patients with scoliosis secondary to Chiari malformation and syringomyelia: does it improve following posterior fossa decompression?
}

Zezhang Zhu, Shifu Sha, Xu Sun, Zhen Liu, Huang Yan, Weiguo Zhu, Jun Jiang ${ }^{*}$, Yong Qiu

From The 10th Meeting of the International Research Society of Spinal Deformities (IRSSD 2014 Sapporo)

Sapporo, Japan. 29 June - 2 July 2014

\section{Objective}

To determine whether denervation of the paraspinal muscles would improve following posterior fossa decompression (PFD) in patients with scoliosis secondary to Chiari malformation and syringomyelia through evaluating the alterations in expression of bax and bcl-2, two genes known to be pivotal for the regulation of cellular apoptosis.

\section{Methods}

Fourteen patients with scoliosis secondary to Chiari malformation and syringomyelia treated between July 2011 and July 2012 were prospectively enrolled. Bilateral biopsy of paraspinal muscles was performed during PFD and subsequent scoliosis surgery. Bax and bcl-2 protein levels were examined by Western blotting and then quantitatively assessed using a scanning densitometer.

\section{Results}

The initial age and primary curve magnitude averaged 16.0 \pm 3.3 years and $63.8^{\circ} \pm 18.3^{\circ}$, respectively. At $7.6 \pm 2.6$ months post-PFD, significant decreases in mean net gray value, positive area and positive ratio were noted for the $20 \mathrm{kd}$ bax protein $(\mathrm{P}=0.021,0.013$ and $<0.001$, respectively). The bcl-2 protein, in contrast, appeared to be enriched over the same period in protein lysates. Specifically, the positive area increased from $10.6 \pm 6.1\left(10^{4}\right)$ to $21.3 \pm 9.2$ $\left(10^{4}\right)(\mathrm{P}=0.001)$, while the positive ratio increased from $0.40 \pm 0.17$ to $0.85 \pm 0.19(\mathrm{P}<0.001)$. Regarding the net gray value, a similar upward trend was observed though

Spine Surgery, Drum Tower Hospital of Nanjing University Medical School, Nanjing, China not reaching statistical significance $(84.4 \pm 35.8$ versus $101.6 \pm 33.3, \mathrm{P}=0.197)$.

\section{Conclusion}

In patients undergoing PFD for Chiari malformation and syringomyelia, myocyte apoptosis could be inhibited through down-regulation of bax and up-regulation of bcl-2, indicating an improvement in denervation of the paraspinal muscles.

Published: 19 January 2015

doi:10.1186/1748-7161-10-S1-011

Cite this article as: Zhu et al:: Denervation of the paraspinal muscles in patients with scoliosis secondary to Chiari malformation and syringomyelia: does it improve following posterior fossa decompression? Scoliosis 2015 10(Suppl 1):011.

Submit your next manuscript to BioMed Central and take full advantage of:

- Convenient online submission

- Thorough peer review

- No space constraints or color figure charges

- Immediate publication on acceptance

- Inclusion in PubMed, CAS, Scopus and Google Scholar

- Research which is freely available for redistribution 